\title{
Risk analysis of the soft targets according to the methodology
}

\author{
Ondřej Zimek ${ }^{*}$ \\ ${ }^{1}$ Tomas Bata University in Zlín, Faculty of Applied Informatics, Nad Stráněmi 4511, 76005 Zlín, Czech Republic.
}

\begin{abstract}
The article deals with the fact that religiously motivated terrorism has become more common in Europe, and more than $50 \%$ of the attacks have been focused on so-called Soft Targets. The purpose of this paper is to make a risk analysis of a particular Soft Target by the Ministry of the Interior methodology. The Tax Office of the Zlin region was chosen as a Soft Target. Auxiliary tables - Likelihood and Impact are necessary for this methodology. Performing an attack, Place of attack, and Time of attack are very important too. The Degree of Threat is determined as the product of Total Likelihood and Total Impact. Risk analysis shows that the highest risk factor is the possibility of a bomb attack that could happen inside the building during the daily working time. The risk analysis should help to find weaknesses of the soft targets, and the security managers should take precautions to reduce the risk.
\end{abstract}

\section{Introduction}

In recent years, religiously motivated terrorist attacks have become more common in Europe [1]. More than $50 \%$ of the attacks have been focused on so-called Soft Targets [2]. Soft Targets are places with a high concentration of people and low or no security measures against terrorism. For example:

-school facilities,

-theatres and cinemas,

-churches and church monuments,

-school facilities,

-canteens, libraries,

-hotels,

-bars, clubs,

-sport halls,

-religious monuments,

-train and bus stations,

-shopping malls $[2,3,4,5]$.

On the other hand, so-called hard targets are crowded places with high-security measures against terrorism. For example, military facilities or government facilities [6,7].

Figure 1 shows that the number of religiously motivated terrorist attacks in the EU is increasing, although paradoxically, the number of victims falls down. The number of religiously motivated terrorist attacks in 2017 was 33. The number of victims fell down to 62 in the same year. The chart also shows that the number of terrorist arrests in the European Union has risen sharply since 2014. The number of attacks was calculated as a sum of realized, failed, and spoiled attacks.

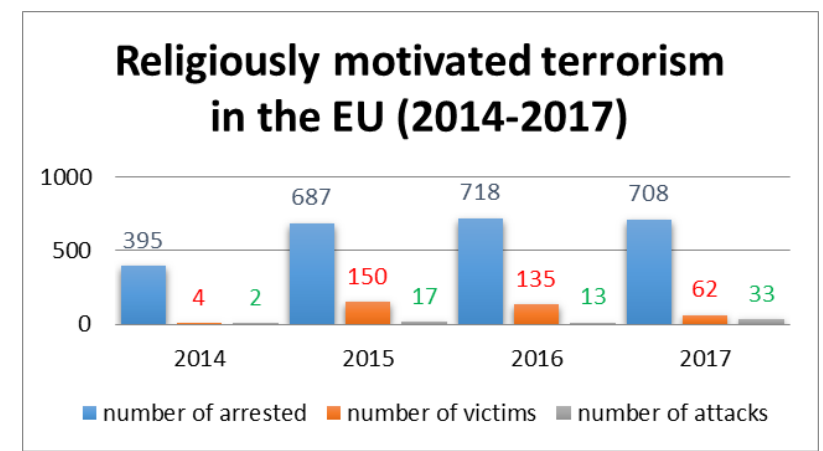

Fig. 1 Religiously motivated terrorism in EU [1].

"European Union Terrorism Situation and Trend Report 2018" states that he number of failed, foiled or completed terrorist attacks occurred on European territory in 2017 increased to value of 205 . The number of arrested suspects in 2017 grew up to value of 1219 . [1]

An important aspect of security is a well-prepared risk analysis. Therefore, the aim of this study is to perform a risk analysis of a particular Soft Target by the Ministry of the Interior methodology. For this purpose, the Tax Office of the Zlin region was chosen as a Soft Target. The risk analysis shows the weaknesses of the chosen Soft Target.

The risk analysis is separated into columns like a Performing an attack, Place of attack, Time of attack, and two auxiliary tables - Likelihood ant Impact. The result of the analysis is a Degree of Threat, which is determined as the product of Total Likelihood, and Total Impact. The results with a high value of Degree of Threat should be reduced to an acceptable risk level by the security managers.

\footnotetext{
* Corresponding author: zimek@utb.cz
} 


\section{Analysis}

The Ministry of the Interior issued a methodological manual "Basics of Soft Targets Protection Guidelines of the Czech Republic" in response to the events related to terrorist attacks. This manual is intended for operators, organizers, and security managers of these subjects.

Table 1 Auxilliary table - Likelihood [2].

\begin{tabular}{|c|c|c|c|}
\hline \multicolumn{4}{|c|}{ Likelihood } \\
\hline $\mathbf{P}$. & Accessibility & Obstacles & Desirability \\
\hline 7 & Without arms & $\begin{array}{c}\text { An individual } \\
\text { without the } \\
\text { assistance of other } \\
\text { people, a public } \\
\text { place }\end{array}$ & $\begin{array}{l}\text { It has already } \\
\text { occurred many } \\
\text { times in the } \\
\text { Czech } \\
\text { Republic }\end{array}$ \\
\hline 6 & $\begin{array}{c}\text { Commonly } \\
\text { available (knife) }\end{array}$ & $\begin{array}{l}\text { It requires the } \\
\text { involvement of } \\
\text { more people, a } \\
\text { public place }\end{array}$ & $\begin{array}{l}\text { It has been in } \\
\text { the relevant } \\
\text { foreign country } \\
\text { many times }\end{array}$ \\
\hline 5 & $\begin{array}{l}\text { More commonly } \\
\text { available } \\
\text { weapons, a } \\
\text { weapon of less } \\
\text { commonly } \\
\text { available (car) }\end{array}$ & $\begin{array}{l}\text { Simple or one-off } \\
\text { cooperation with } \\
\text { local criminal } \\
\text { a group, a public } \\
\text { place }\end{array}$ & $\begin{array}{l}\text { It has appeared } \\
\text { several times in } \\
\text { the Czech } \\
\text { Republic }\end{array}$ \\
\hline 4 & $\begin{array}{l}\text { Gun on Permit or } \\
\text { More, (Firearm) }\end{array}$ & $\begin{array}{l}\text { More complicated } \\
\text { or longer-term } \\
\text { cooperation with } \\
\text { the criminal group } \\
\text { of the public is } \\
\text { inaccessible }\end{array}$ & $\begin{array}{l}\text { It has appeared } \\
\text { several times in } \\
\text { relevant } \\
\text { foreign } \\
\text { countries }\end{array}$ \\
\hline 3 & $\begin{array}{c}\text { A weapon } \\
\text { obtainable by } \\
\text { criminal activity } \\
\text { (black market, } \\
\text { etc.) without the } \\
\text { need for } \\
\text { professional } \\
\text { training } \\
\end{array}$ & $\begin{array}{c}\text { One-time talks } \\
\text { with a local } \\
\text { terrorist group, a } \\
\text { public inaccessible } \\
\text { place }\end{array}$ & $\begin{array}{l}\text { It occurred } \\
\text { rarely in the } \\
\text { Czech } \\
\text { Republic }\end{array}$ \\
\hline 2 & $\begin{array}{l}\text { A weapon that } \\
\text { can be acquired } \\
\text { by criminal } \\
\text { activities with the } \\
\text { need for } \\
\text { professional } \\
\text { training with } \\
\text { short delivery } \\
\text { times }\end{array}$ & $\begin{array}{c}\text { Coordinated } \\
\text { actions at the local } \\
\text { level with } \\
\text { cooperation with a } \\
\text { terrorist group, } \\
\text { public inaccessible } \\
\text { place }\end{array}$ & $\begin{array}{l}\text { It has rarely } \\
\text { occurred in the } \\
\text { relevant } \\
\text { foreign } \\
\text { countries }\end{array}$ \\
\hline 1 & $\begin{array}{l}\text { The weapon can } \\
\text { be obtained by } \\
\text { criminal activity } \\
\text { with the need for } \\
\text { professional } \\
\text { training and long } \\
\text { delivery times }\end{array}$ & $\begin{array}{c}\text { Internationally } \\
\text { coordinated action } \\
\text { by a terrorist } \\
\text { group, accessible } \\
\text { to the public or } \\
\text { inaccessible to the } \\
\text { public }\end{array}$ & $\begin{array}{l}\text { It never } \\
\text { appeared in the } \\
\text { Czech } \\
\text { Republic or in } \\
\text { the relevant } \\
\text { foreign } \\
\text { countries }\end{array}$ \\
\hline
\end{tabular}

Table 1 shows the auxiliary table for determine Likelihood value. The Likelihood is separated into three categories. Every category has range of values from 1 to 7 points. As can be seen, value 1 represents the lowest likelihood. On the other hand, the highest Likelihood is represented by value of 7 points. The Total Likelihood is calculated as the sum of Accessibility, Obstacles and Desirability with a maximum value of 21 .

Table 2 Auxilliary table - Impact [2]

\begin{tabular}{|c|c|c|c|c|}
\hline \multicolumn{5}{|c|}{ Impact } \\
\hline P. & $\begin{array}{c}\text { Damage to } \\
\text { building }\end{array}$ & $\begin{array}{c}\text { Threat to } \\
\text { lives }\end{array}$ & \begin{tabular}{|l|} 
Impact on \\
community
\end{tabular} & $\begin{array}{c}\begin{array}{c}\text { Economical } \\
\text { losses }\end{array} \\
\end{array}$ \\
\hline 7 & $\begin{array}{l}\text { Destruction } \\
\text { of the } \\
\text { object, } \\
\text { eventually } \\
\text { static } \\
\text { disruption, } \\
\text { cancellation } \\
\text { of the event }\end{array}$ & $\begin{array}{l}\text { Serious } \\
\text { injuries to } \\
\text { more } \\
\text { people and } \\
\text { the death } \\
\text { of more } \\
\text { people }\end{array}$ & $\begin{array}{c}\text { Termination } \\
\text { of } \\
\text { participation } \\
\text { / activity }\end{array}$ & $\begin{array}{l}\text { Impact } \\
\text { economically } \\
\text { liquidated }\end{array}$ \\
\hline 6 & $\begin{array}{c}\text { Extensive } \\
\text { limitation of } \\
\text { the } \\
\text { functionality } \\
\text { of an object } \\
\text { or } \\
\text { possibility } \\
\text { of } \\
\text { organizing } \\
\text { an event }\end{array}$ & $\begin{array}{l}\text { Serious } \\
\text { injuries to } \\
\text { more } \\
\text { people and } \\
\text { death of } \\
\text { individuals }\end{array}$ & $\begin{array}{l}\text { Temporary } \\
\text { interruption } \\
\text { of activity }\end{array}$ & $\begin{array}{c}\text { Impact over } \\
\text { CZK 500,000, } \\
\text { insurable by } \\
\text { insurance }\end{array}$ \\
\hline 5 & $\begin{array}{l}\text { Limit the } \\
\text { functionality } \\
\text { of part of } \\
\text { the object or } \\
\text { part of the } \\
\text { action }\end{array}$ & $\begin{array}{l}\text { Serious } \\
\text { injuries to } \\
\text { more } \\
\text { people }\end{array}$ & $\begin{array}{l}\text { Real risk of } \\
\text { people } \\
\text { being } \\
\text { involved in } \\
\text { other } \\
\text { activities }\end{array}$ & $\begin{array}{c}\text { Impact over } \\
\text { CZK 100,000, } \\
\text { insurable by } \\
\text { insurance }\end{array}$ \\
\hline 4 & $\begin{array}{c}\text { Local } \\
\text { limitation of } \\
\text { the } \\
\text { functionality } \\
\text { of the room } \\
\text { or part of } \\
\text { the action }\end{array}$ & $\begin{array}{c}\text { Serious } \\
\text { injury to } \\
\text { individuals }\end{array}$ & $\begin{array}{c}\text { General } \\
\text { concern to } \\
\text { be active in } \\
\text { the } \\
\text { community, } \\
\text { more } \\
\text { limitation of } \\
\text { activities }\end{array}$ & $\begin{array}{l}\text { Impact over } \\
\text { CZK 100,000, } \\
\text { solvable by } \\
\text { insurance }\end{array}$ \\
\hline 3 & $\begin{array}{l}\text { Serious } \\
\text { damage to } \\
\text { the object or } \\
\text { disturbance } \\
\text { of the action } \\
\text { without } \\
\text { limitation of } \\
\text { functionality }\end{array}$ & $\begin{array}{l}\text { Light } \\
\text { injuries to } \\
\text { more } \\
\text { people }\end{array}$ & $\begin{array}{l}\text { Less } \\
\text { activity } \\
\text { restrictions }\end{array}$ & $\begin{array}{l}\text { Impact in the } \\
\text { order of tens } \\
\text { of thousands }\end{array}$ \\
\hline 2 & $\begin{array}{l}\text { Minor } \\
\text { damage to } \\
\text { the object or } \\
\text { disturbance } \\
\text { of the action } \\
\text { without } \\
\text { limitation of } \\
\text { functionality }\end{array}$ & $\begin{array}{l}\text { Light } \\
\text { injuries to } \\
\text { individuals }\end{array}$ & $\begin{array}{c}\text { Poor impact } \\
\text { on } \\
\text { individuals }\end{array}$ & $\begin{array}{l}\text { Impact to } \\
5000 \mathrm{CZK}\end{array}$ \\
\hline 1 & $\begin{array}{c}\text { No or } \\
\text { negligible } \\
\text { object } \\
\text { damage or } \\
\text { action } \\
\text { disruption }\end{array}$ & $\begin{array}{l}\text { Shock or } \\
\text { minor } \\
\text { injuries }\end{array}$ & $\begin{array}{l}\text { Without an } \\
\text { obvious } \\
\text { impact on } \\
\text { the } \\
\text { community }\end{array}$ & $\begin{array}{c}\text { No impact, or } \\
\text { negligible }\end{array}$ \\
\hline
\end{tabular}


Table 2 shows the auxiliary table for determine Impact Value. The Impact is separated into four categories. Every category has range of values from 1 to 7 points. As can be seen, value 1 represents the lowest Impact Value. On the other hand, the highest Impact is represented by value of 7 points. The Total Impact Value is calculated as the sum of Damage to Building, Threat to Lives, Impact on Community and Economic losses which can result in a maximum value of 28 . Reduce the impact of terrorist attacks is desirable.

The Degree of Threat is determined as the product of Total Likelihood and Total Impact with a maximum value of 588 and minimum value of 12 [2,8].

Table 3 Risk analysis of the Tax Office.

\begin{tabular}{|c|c|c|c|c|c|c|c|c|c|c|c|c|}
\hline \multirow[b]{2}{*}{ 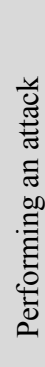 } & \multirow[b]{2}{*}{ 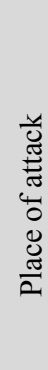 } & \multirow[b]{2}{*}{ 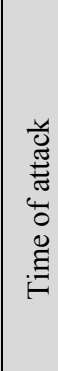 } & \multicolumn{4}{|c|}{ Likelihood } & \multicolumn{5}{|c|}{ Impact } & \multirow[b]{2}{*}{ 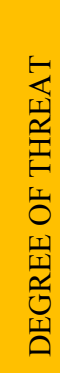 } \\
\hline & & & 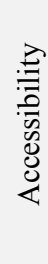 & $\begin{array}{l}\frac{\tilde{o}}{\tilde{U}} \\
\tilde{\tilde{w}} \\
0 \\
0\end{array}$ & 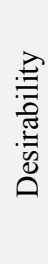 & 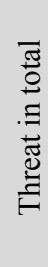 & 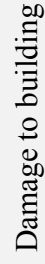 & 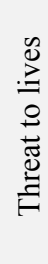 & 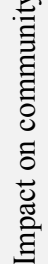 & 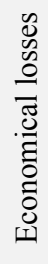 & 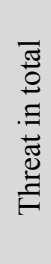 & \\
\hline K & IF & D & 6 & 7 & 6 & 19 & 1 & 4 & 4 & 3 & 12 & 228 \\
\hline K & IF & E & 6 & 7 & 4 & 17 & 1 & 5 & 3 & 2 & 11 & 187 \\
\hline K & IS & D & 6 & 7 & 6 & 19 & 1 & 4 & 4 & 2 & 11 & 209 \\
\hline $\mathrm{K}$ & IS & $\mathrm{E}$ & 6 & 7 & 4 & 17 & 1 & 4 & 5 & 3 & 13 & 221 \\
\hline $\mathrm{S}$ & IF & $\mathrm{D}$ & 3 & 7 & 6 & 16 & 2 & 6 & 5 & 2 & 15 & 240 \\
\hline $\mathrm{C}$ & IF & E & 3 & 7 & 4 & 14 & 2 & 6 & 4 & 3 & 15 & 210 \\
\hline B & IS & D & 2 & 7 & 6 & 15 & 7 & 7 & 5 & 6 & 25 & 375 \\
\hline A & IF & E & 2 & 3 & 4 & 9 & 3 & 5 & 4 & 5 & 17 & 153 \\
\hline
\end{tabular}

Table 3 shows the calculation of the Degree of Threat of the Tax Office.

Column Performing an attack shows modus operandi of attack. For this paper were chosen these attacks:

A-Assassination

B-Bomb

C-Attack by car

K-Knife Attack

S-Shooting

Column Place of Attack determines, if the attack could happen in front of building (IF) or inside the building (IS)

Time of Attack determines, if the attack could happen by the daily working time (D) or Event for invited (E).

Each security manager determines an acceptable risk level. The author considers the value of 192 as a possibly acceptable risk level. Every higher value should be reduced to an acceptable risk level. However, this value is only indicative, and site security managers should work with it.
The risk analysis shows that the lowest risk factor with the value of 153 means that an assassination could happen during an event for invited guests. Moreover, it could happen inside or outside the building. On the contrary, the highest risk factor is the possibility of a bomb attack that could happen inside the building during the daily working time, and its value is 375 .

The owner of the soft target, or the site security manager, should take these values into account and take precautions to reduce the risk.

\section{Conclusion}

This paper deals with the fact that most of the terrorist attacks that occurred in Europe were aimed at so-called Soft Targets. Therefore, a risk analysis was performed according to the methodology of the Ministry of the Interior ("Basics of Soft Targets Protection Guidelines of the Czech Republic"), and it was compiled for a specific soft target (Regional Office).

The risk analysis shows that the highest risk factor with the value of 375 for the Zlin Regional Office is a bomb attack inside the building during the daily working time. The paper further specifies that the lowest risk factor with the value of 153 means that an assassination could happen during an event for invited guests, both inside or outside the building. This analysis should help security managers in the risk identification and its subsequent reduction to an acceptable risk level. A very important aspect of protecting a soft target is prevention. One of the challenges for future research is to develop a new auxiliary table for the part of Performing an attack.

Acknowledgement: This work was supported by the Internal Grant Agency of Tomas Bata University under the project No. IGA/FAI/2019/003.

\section{References}

1. TESAT, EUROPOL (2018)

2. Z. Kalvach, G. (2016)

3. P. Beňová, Š. Hošková - Mayerová, J. Navrátil, JSSI (2019)

4. L. Figuli, Z. Kubíková and M. Ivančo, IDCS 17(1A), (2019)

5. L. Duricova, M. Hromada, J.Mrazek, PIDGSSW (2017)

6. J. Hesterman, STCM (2017)

7. M. Zineddin \& L. Sherwood, WIT TTBE, (2013)

8. Š. Hošková - Mayerová, FA 16 (2016) 